\title{
Pollination and dispersal trait spectra recover faster than the growth form spectrum during spontaneous succession in sandy old-fields
}

\author{
Edy Fantinato $^{1}$ (D) | Judit Sonkoly ${ }^{2,3}$ (D) | Giulia Silan ${ }^{1}$ (D) | Orsolya Valkó ${ }^{2}$ | \\ Béla Tóthmérész $^{2}$ | Balázs Deák ${ }^{4}$ | András Kelemen ${ }^{2,5}$ (D) | Tamás Miglécz ${ }^{2}$ | \\ Silvia Del Vecchio ${ }^{1}$ (D) | Francesca Bettiol ${ }^{1}$ | Gabriella Buffa ${ }^{1}$ (D) | Péter Török ${ }^{2,3}$
}

${ }^{1}$ Department of Environmental Science, Informatics and Statistics, Ca' Foscari University of Venice, Venice, Italy

${ }^{2}$ Department of Ecology, University of Debrecen, Debrecen, Hungary

${ }^{3}$ MTA-DE Lendület Functional and Restoration Ecology Research Group, Debrecen, Hungary

${ }^{4}$ MTA-DE Biodiversity and Ecosystem Services Research Group, Debrecen, Hungary

${ }^{5}$ MTA's Premium Postdoctoral Research Programme, Budapest, Hungary

\section{Correspondence}

Edy Fantinato, Department of Environmental Science, Informatics and Statistics, $\mathrm{Ca}^{\prime}$ Foscari University of Venice, Venice, Italy. Email:edy.fantinato@unive.it

Funding information

The authors were supported by MTA's Post Doctoral Research Program (AK), NKFI KH 130338 (BD), NKFI K 116239 (BT), NKFI KH 126477 (BT), the Bolyai János Fellowship of the Hungarian Academy of Sciences (BD, $\mathrm{OV})$, the Ca' Foscari University of Venice and MIUR (EF), NTP-NFTÖ-18-B by the Ministry of Human Capacities (JS), NKFI FK 124404 (OV), NKFI KH 126476 (OV), NKFIH K 119225 (PT), NKFI KH 129483 (PT), and NKFI PD 124548 (TM).

Co-ordinating Editor: Guillaume Decocq

\begin{abstract}
Question: Spontaneous succession is the most natural and cost-effective solution for grassland restoration. However, little is known about the time required for the recovery of grassland functionality, i.e., for the recovery of reproductive and vegetative processes typical of pristine grasslands. Since these processes operate at different scales, we addressed the question: do reproductive and vegetative processes require different recovery times during spontaneous succession?

Location: Kiskunság sand region (Central Hungary).

Methods: As combinations of plant traits can be used to highlight general patterns in ecological processes, we compared reproductive (pollination- and dispersal-related) and vegetative (growth form) traits between recovered grasslands of different age (<10 years old; $10-20$ years old; $20-40$ years old) and pristine grasslands.

Results: During spontaneous succession, the reproductive trait spectra became similar to those of pristine grasslands earlier than the vegetative ones. In arable land abandoned for 10 years, pollination- and dispersal-related trait spectra did not show significant difference to those of pristine grasslands; anemophily and anemochory were the prevailing strategies. Contrarily, significant differences in the growth form spectrum could be observed even after 40 years of abandonment; in recovered grasslands erect leafy species prevailed, while the fraction of dwarf shrubs and tussock-forming species was significantly lower than in pristine grasslands.

Conclusions: The recovery of the ecological processes of pristine grasslands might require different amounts of time, depending on the spatial scale at which they operate. The reproductive trait spectra recovered earlier than the vegetative one, since reproductive attributes first determine plant species sorting at the regional level towards their respective habitats. The recovery of the vegetative trait spectrum needs more time as vegetative-based interactions operate on a smaller spatial scale. Thus, vegetative traits might be more effective in the long-term assessment of restoration success than the reproductive ones.
\end{abstract}


KEYWORDS

dispersal, grassland recovery, growth form, old-field succession, pollination, reproductive traits, restoration, spontaneous succession, vegetative traits

\section{1 | INTRODUCTION}

Before the twentieth century, pristine and semi-natural grasslands represented a constant element in agro-ecosystems all around Europe (Prach, Jongepierová, Řehounková, \& Fajmon, 2014). During the twentieth century, socio-economic changes in Europe led to an increasing loss of grassland surface due to either their conversion to arable land (Edwards et al., 2007; Pullin et al., 2009), or the abandonment of traditional management practices (Valkó, Török, Matus, \& Tóthmérész, 2012). More recently, a renewed interest in pristine and semi-natural grasslands has arisen (e.g., Dengler, Janišová, Török, \& Wellstein, 2014; Wellstein et al., 2014), because their decline has caused the loss of many ecosystem services (Bastian, 2013; Kahmen, Perner, \& Buchmann, 2005). Indeed, pristine and semi-natural grasslands play an important role in nutrient cycling, carbon sequestration and balancing of the local climate (Jones \& Donnelly, 2004), they prevent soil erosion (Bastian, 2013), and provide pollinators and biological control agents to co-occurring croplands (Fantinato, Del Vecchio, Gaetan, \& Buffa, 2019; Öckinger \& Smith, 2007). Accordingly, considerable efforts have been devoted to pristine and semi-natural grassland conservation and restoration. Because of the recent widespread cessation of formal agricultural practices in many European regions, large areas of old-field have become available for the restoration of grassland ecosystems, and many restoration programs based on technical reclamation and/or on spontaneous succession have been implemented (Hedberg \& Kotowski, 2010; Kiehl, Kirmer, Donath, Rasran, \& Hölzel, 2010; Török, Vida, Deák, Lengyel, \& Tóthmérész, 2011).

Grassland recovery by spontaneous succession represents a cost-effective and the most natural solution for grassland restoration, and it can effectively substitute technical reclamation methods in slightly fragmented landscapes, when propagule sources are nearby (Prach \& Hobbs, 2008). Spontaneous grassland succession relies on locally available supplies of propagules, which include soil seed bank and seed rain mediated by different seed-dispersing agents from adjacent plant communities (Prach et al., 2016; Török et al., 2011). Studies on spontaneous succession proved that generally the basic grassland species pool is reconstituted in a relatively short time span (e.g., 10-20 years; Albert et al., 2014). Even though this approach has received considerable attention, little is known about the spontaneous recovery of grassland functionality, i.e., the recovery of fundamental ecological processes and structures typical of pristine grasslands, which ultimately assures the provision of ecosystem services (Kandziora, Burkhard, \& Müller, 2013).

Processes linked to both sexual reproduction and vegetative growth influence plant community functionality by exerting selective pressure on plant species composition and assemblage
(Armbruster, 1995; Slaviero, Del Vecchio, Pierce, Fantinato, \& Buffa, 2016). At the regional scale, reproductive processes involving pollination and seed dispersal are crucial because the production of seeds is necessary for the colonization of new sites (Escaravage \& Wagner, 2004). Furthermore, in some plant communities, they also contribute to shaping patterns of species cooccurrence at smaller scales (Fantinato, Del Vecchio, Giovanetti, Acosta, \& Buffa, 2018; Heystek \& Pauw, 2014). Processes linked to vegetative reproduction and growth in plant communities influence species co-occurrence at a small spatial scale through interactions as competition for light, space and below-ground resources (Kelemen et al., 2015; van der Maarel \& Sykes, 1993). In this context, combinations of plant traits at the community level are considered by several authors as potential predictors of general patterns of reproductive and vegetative processes (e.g., Catorci, Cesaretti, Gatti, \& Tardella, 2012; Chelli et al., 2019; Schamp, Hettenbergerová, \& Hájek, 2011).

Since reproductive and vegetative processes operate on different scales and at different stages of plant community assembly, we investigated whether their recovery times were different during spontaneous succession. We addressed the problem by comparing the spectra of reproductive (pollination- and dispersal-related) and vegetative (growth form) traits between old-fields of different age and pristine grasslands chosen as reference state. In particular, we assessed which of the two sets of plant traits in old-field spontaneous succession first showed a spectrum comparable to that of pristine grasslands.

\section{2 | METHODS}

\subsection{Site selection and data collection}

The study site is located at the centre of the Pannonian biogeographic region, in the calcareous sand region of Kiskunság within a $5 \mathrm{~km}$ radius of $46^{\circ} 50^{\prime} 30^{\prime \prime} \mathrm{N}, 1^{\circ} 26^{\prime} 13^{\prime \prime} \mathrm{E}$. The region has a continental climate with a considerable sub-Mediterranean influence. The mean annual temperature is $10^{\circ} \mathrm{C}$ and the mean annual precipitation is $500 \mathrm{~mm}-550 \mathrm{~mm}$, with a semiarid period in late summer (Kelemen et al., 2016). The region is characterised by calcareous sandy soils with low water retention capacity, $\mathrm{pH}$ up to 8.1 and $\mathrm{CaCO}_{3}$ content of 7.3\% (Csecserits et al., 2011). The most widespread native grassland vegetation types are open sand grasslands developing near and at the top of sand dunes, and closed sand grasslands at lower elevations and in dune slacks. Open sand grassland vegetation belongs to Festucetum vaginatae, with Festuca vaginata and Stipa borysthenica as characteristic frequent graminoids, while closed sand grassland vegetation belongs to the Galio veri-Holoschoenetum vulgaris 
association, with Scirpoides holoschoenus, and Stipa capillata as typical species (Borhidi, Kevey, \& Lendvai, 2012).

During the socialist regime, large areas of sand dunes were ploughed and pristine grasslands were substituted with croplands. The abandonment of croplands in Kiskunság started in the 1960s and intensified after the collapse of the socialist regime at the end of the 1980s (Biró, Révész, Molnár, Horváth, \& Czúcz, 2008; Török, Matus, Papp, \& Tóthmérész, 2008). After the abandonment, croplands experienced spontaneous succession and nowadays old-fields of different ages can be found in the region. Based on historical maps, aerial photographs and local ranger knowledge, 12 old-fields were classified into three age groups (four old-fields per group): young ( $<10$ years old), middle-aged (10-20 years old) and late succession (20-40 years old). The studied old-fields were grazed or mown occasionally. For a detailed description of the three age groups see Albert et al. (2014). During the socialist regime sand dunes were flattened to ease agricultural activities, and old-fields are now in an intermediate position between open sand grasslands developing near and at the top of sand dunes (Festucetum vaginatae association), and closed sand grasslands at lower elevations and in dune slacks (Galio veri-Holoschoenetum vulgaris association). Therefore, since it is not possible to predict whether succession will proceed towards the open or the closed sand grassland association, three open and three closed pristine sand grasslands were sampled as baseline vegetation reference.

We selected one $5 \mathrm{~m} \times 20 \mathrm{~m}$ sample site in each old-field and reference grassland, avoiding the margins, and we recorded the list of vascular plant species in five $2 \mathrm{~m} \times 2 \mathrm{~m}$ plots in each site. The plots were evenly distributed within the selected site by placing them in the centre of five $5 \mathrm{~m} \times 4 \mathrm{~m}$ subsections. Overall, 20 plots were recorded in each old-field age group (i.e., young, middle-aged and late succession old-fields), summing up to a total of 60 plots, while 30 plots were surveyed in reference grasslands: 15 in open and 15 in closed reference grasslands. The list of vascular plant species was recorded during two surveys in early May and in late June 2012.

\section{2 | Plant traits}

For each species, we collected data regarding both reproductive (pollination- and dispersal-related) and vegetative (growth forms) traits (Appendix S1).

The pollination strategy of angiosperms was derived from their floral morphology, by using the Kugler (1970) classification from the BiolFlor database (Kühn, Durka, \& Klotz, 2004). In fact, angiosperms produce recognisably convergent floral morphologies which recur in flowers of different evolutionary origin that share similar pollinator guilds (Fantinato, Del Vecchio, Slaviero, Conti, Acosta, \& Buffa, 2016; Thomson \& Wilson, 2008). We regrouped floral morphology types into five main categories occurring in our study area: inconspicuous (i.e., wind-pollinated), disk (including head inflorescences; Pellissier, Pottier, Vittoz, Dubuis, \& Guisan, 2010), funnel, tube, and bilabiate floral morphology. These floral morphologies represent discrete classes along the continuum between specialization and generalization. Specialised species are usually characterised by complex (either actinomorphic or zygomorphic) flowers with floral resources totally hidden at the bottom of a long corolla tube (i.e., tube and bilabiate flowers; Westerkamp $\&$ Claßen-Bockhoff, 2007), while generalists usually present simple, actinomorphic flowers with easily accessible resources (disk and funnel flowers). Even though caution is necessary when pollination interactions of a single species are inferred from its floral morphology (e.g., Fantinato, Del Vecchio, Baltieri, Fabris, \& Buffa, 2017), the spectrum of floral morphologies at the community level may be indicative of prevailing trends (Fantinato, Giovanetti, Del Vecchio, \& Buffa, 2016).

Based on the classifications of Müller-Schneider (1986) and Vittoz and Engler (2007), species were categorised into one of five general dispersal modes: anemochory, autochory, endozoochory, epizoochory and hemerochory. Anemochorous species usually present diaspores with pappus, wings, or are sufficiently small and light to be dispersed by wind. Autochorous species are those with diaspores that exhibit explosive dehiscence or that lack an evident dispersal mechanism (Cortés-Flores, Andresen, Cornejo-Tenorio, \& Ibarra-Manriquez, 2013). In endozoochorous and epizoochorous species, the dispersion of diaspores is mediated by animals, through ingestion and subsequent dispersion (endozoochory) or through unintentional transportation (epizoochory). Lastly, in hemerochorous species, the vector of diaspore dispersion is represented by humans. In the case of species using more than one dispersal vector, we chose the prevailing strategy.

Growth forms reveal the space occupation strategy of plant species (e.g., Cornelissen et al., 2003; Liira, Zobel, Mägi, \& Molenberghs, 2002; Mason, Pipenbaher, Škornik, \& Kaligarič, 2013), therefore they deeply influence plant community organisation and functioning (Del Vecchio, Slaviero, Fantinato, \& Buffa, 2016). Following Cornelissen et al. (2003), plant species were assigned the following growth forms: creeping (reptant herbaceous species with a prostrate form), dwarf shrub (woody plants up to $0.8 \mathrm{~m}$ tall), erect leafy (plant essentially erect, leaves concentrated in middle and/or top parts), short basal (leaves $<0.5 \mathrm{~m}$ long concentrated very close to the soil surface, e.g., rosette plants), and tussock (many leaves from basal meristem forming prominent tufts) growth

\section{3 | Data analysis}

For each plot, we calculated the percentage of plant species with different (a) pollination strategies, (b) dispersal modes, and (c) growth forms. To test for significant differences in the proportions of pollination strategies, dispersal modes and growth forms between recovered old-fields and reference grasslands (i.e., young, middle-aged and late-successional fields vs open and closed reference grasslands), we performed one-way PERMANOVA applying the Bray-Curtis similarity index with 9,999 randomizations and the Tukey test (Anderson \& Ter Braak, 2003). PERMANOVA and Tukey tests were performed with PAST software (Hammer, Harper, \& Ryan, 2001). 
TAB LE 1 Mean number of species per trait calculated for each old-field and grassland type (mean $\pm S D$ )



\section{3 | RESULTS}

Overall, in the study area, we identified 103 plant species, of which 48 were present only in the old fields and 17 only in the reference grasslands, while 38 were shared between old-fields and reference grasslands. Only 14 were present in all old-fields and reference grassland types. Prevailing strategies arose from the assessment of reproductive and vegetative traits (Table 1 ). The majority of plant species were pollinated by animals (69 species). However, at the plot level, inconspicuous flowers were the most represented, regardless of the old-field age or reference grassland type (Table 1). Beside pollen dispersal, wind was also the most frequent vector of seed dispersal, with 57 anemochorous species recorded. This was reflected at the plot level, with anemochorous species prevailing over other dispersal strategies in all the old-fields and reference grassland types (Table 1). Lastly, among growth forms, erect leafy was the prevalent one (71 species), as reflected also at the plot level (Table 1). However, though prevailing strategies could be observed, differences in the spectra of reproductive and vegetative traits between old-fields and reference grasslands were revealed by PERMANOVA (Pseudo- $F=12.74 ; p=0.0001$ ). The Tukey test indicated that pollination strategies differed significantly only between young fields and all the other categories (the other two old-field age groups and reference grasslands), with the proportion of species with inconspicuous flowers being significantly lower in the young fields (Figure 1). No significant differences were revealed between old-fields and reference grasslands in the proportion of plant species with disk and funnel flowers (i.e., generalist entomophilous species; Figure 1). On the other hand, plant species with tube and bilabiate flowers (specialist entomophilous species) were more represented in the young fields than in middle-aged and late-successional old-fields, and in reference grasslands (Figure 1 ).

Significant differences were revealed between young and middle-aged old-fields and reference grasslands regarding dispersal modes. The proportion of autochorous species was shown to have already reached the level of open reference grasslands in middleaged fields; meanwhile, the proportion of autochorous species in the young fields was not different from that found in closed reference grasslands (Figure 1). The proportion of anemochorous species was significantly higher in late-successional old-fields and reference grasslands than in young and middle-aged old-fields (Figure 1). On the contrary, young fields showed a significantly higher proportion of epizoochorous species than middle-aged and late-successional old-fields and reference grasslands. No significant differences were revealed for the endozoochorous species (Figure 1). Lastly, the proportion of hemerochorous species was much higher in young and middle-aged old-fields than in late-successional old-fields and reference grasslands, while no differences could be observed between late-successional old-fields and reference grasslands (Figure 1).

On the contrary, regardless of age, old-fields significantly differed from reference grasslands in the proportions of all vegetative 



FIGURE 1 Proportions of floral morphologies (left graphs), dispersal modes (central graphs) and growth forms (right graphs) in differently aged old-fields and reference grasslands (median and percentiles are shown; outliers are represented by asterisks). Proportions are based on species number. Different letters indicate significant differences according to Tukey's test $(p<0.05)$

growth forms with the exception of creeping species (Figure 1). In particular, erect leafy species prevailed in old-fields (Figure 1), while the proportions of dwarf shrubs and tussock forming species were significantly lower (Figure 1). Furthermore, the proportion of rosette-forming species was higher in the young fields than in reference grasslands (Figure 1).

\section{4 | DISCUSSION}

Our results revealed that during spontaneous succession the composition of reproductive (pollination- and dispersal-related) traits in recovered grasslands became similar to that of pristine grasslands earlier than growth forms did. 
Plant traits related to pollination and seed dispersal assumed proportions comparable to those of reference grasslands very early in the succession. With regard to pollination strategies, significant differences could be detected only between young fields and reference grasslands: the proportion of specialist entomophilous species (i.e., plant species with bilabiate and tube-shaped flowers) was significantly higher in the young fields than in reference grasslands, while the proportion of wind-pollinated species was significantly lower. According to Vamosi, Armbruster, and Renner (2014), physiological constraints may act to allow for specialization along alternate facets of a species' life history, namely, an increased specialization for one guild of pollinators or in inhabiting one niche should come at the expense of specializing for another aspect of the plant life history. Our observations are in line with this hypothesis; in fact, we found that annual weed species, which are well-known habitat generalist species and typical of the young fields (Albert et al., 2014), were highly specialized for bees (e.g., Lamium amplexicaule, Vicia villosa) or butterflies (e.g., Silene latifolia). After the cessation of former agricultural practices, spontaneous succession typically leads to the establishment of competitive perennial species (Osbornová, Kovářová, Lepš, \& Prach, 1990), which ultimately hinders the establishment and persistence of annual weed species through competition for light and belowground resources. Given these conditions, which see a relatively low number of perennials become dominant in the community, wind pollination becomes the most efficient strategy. In fact, wind pollination is an efficient and straightforward way of moving pollen between plants in open habitats, where large stands of a particular species are present (Willmer, 2011).

Similar to pollination strategies, dispersal modes also seemed to be influenced by past agricultural practices; we observed that hemerochorous species prevailed in young and middle-aged oldfields. Humans can either intentionally or unintentionally disperse seeds from a wide range of plants over long distances, especially in croplands and urbanised areas (Poschlod, Bakker, \& Kahmen, 2005). Therefore, after the interruption of agricultural practices, these species might face huge decline, resulting in a lower proportion of hemerochorous species in late-successional old-fields as well as in reference grasslands. On the other hand, anemochory and autochory showed opposite trends. As time passes, decreasing nutrient levels in old-fields and increasing community stability might favour the establishment of plant species that adopt a more conservative dispersal strategy (i.e., autochorous and anemochorous species; Jentsch \& Beyschlag, 2003). Epizoochory, on the other hand, which is widely recognized as an effective long-distance seed dispersal mechanism (Couvreur, Christiaen, Verheyen, \& Hermy, 2004), is more advantageous under the disturbed and unstable conditions typical of the young fields.

Interestingly, in contrast with pollination- and dispersal-related trait spectra, old-field proportions of plant species growth forms (i.e., erect leafy, tussock and dwarf shrub growth forms) were still significantly different from reference grasslands even 20-40 years after ploughing has stopped. It has been well documented that in abandoned croplands where perennial species can grow, larger plants become dominant over time by producing a dense litter layer and shading canopies, thus triggering competitive interactions for space and belowground resources (Aarssen, Schamp, \& Pither, 2006; Grime, 2001). Moreover, during secondary succession, the progressive reduction of belowground resources will ultimately lead to more stress-tolerant species becoming dominant; these are generally characterised by tussock and dwarf shrub growth forms (e.g., Bakker \& van Diggelen, 2006; Hurst \& John, 1999). In our case, regardless of old-field age, erect leafy species were still overrepresented, while tussocks and dwarf shrubs were underrepresented, suggesting that competitive interactions in old-fields have not yet effectively influenced the community assembly structure by means of growth form selection (Pérez-Harguindeguy et al., 2013). Short basal plants, which have been proven to be especially sensitive to interspecific competition due to their prostrate growth form (Keddy, Nielsen, Weiher, \& Lawson, 2002; Reader \& Best, 1989; Wilson \& Keddy, 1986), showed a proportion comparable to that of reference grasslands already in the middle-aged old-fields. Our results confirm the findings of Purschke et al. (2013), suggesting that competitive exclusion plays a relatively important role in species assemblage dynamics during the late phases of succession; instead, local environmental conditions are more influential during early stages, with nitrophilous species (e.g., erect leafy like Ambrosia artemisiifolia, Anthemis ruthenica, Secale sylvestre) being favoured over stress-tolerant species (e.g., tussock-forming grasses and dwarf shrubs like F. vaginata and Salix rosmarinifolia) by the conspicuous amount of residual soil nutrients.

In a broader perspective, the presence of a particular plant species in a local community can be interpreted as the result of a series of filters operating a selection based on species traits from a regional pool into a local community, reflecting their differential ecological characteristics (Keddy, 1992). According to the assembly rules hypothesis (Götzenberger et al., 2012; Wilson, 1999; Wilson \& Gitay, 1995), the arrival of a species into a local community is strongly constrained by its seed production and spatial dispersal; meanwhile, the establishment of a species is affected by local environmental conditions and by complex vegetative interactions with co-occurring species (Armbruster, 1995). We can assume from the results that reproductive (pollination- and dispersal-related) community traits recover more rapidly than vegetative ones (growth forms), since these attributes first determine plant species sorting at the regional level towards their respective habitats. The recovery of the vegetative trait spectrum needs more time as interactions based on vegetative growth and vegetative spread operate on a smaller spatial scale, in addition to being highly affected by local abiotic conditions and by interspecific competition for space and belowground resources. In summary, the recovery of the ecological processes that characterise pristine grassland communities might require different amounts of time during spontaneous grassland succession, depending on the spatial scale at which a particular process operates and on the impact of past cropland management practices on the local environmental conditions.

Certainly, our findings deserve further investigation, but they might contribute with original new insights to the understanding of 
spontaneous succession in sandy old-fields. In this context, the most important take-home message of the current study is that the analysis of trait spectra at the community level may provide a valuable tool for the assessment of restoration success in sandy old-fields. Overall, "soft" traits, besides being less difficult and expensive to obtain than "hard" traits, proved effective in detecting different stages of assembly processes after cropland abandonment. However, our approach also highlighted that vegetative traits are informative on the successful restoration at different timescales. As the reproductive trait spectrum (pollination- and dispersal-related) recovers more quickly than the vegetative trait (growth form) spectrum, vegetative traits might be more effective in the assessment of restoration success than the reproductive ones.

\section{ORCID}

Edy Fantinato (iD https://orcid.org/0000-0003-0114-4738

Judit Sonkoly (iD https://orcid.org/0000-0002-4301-5240

Giulia Silan iD https://orcid.org/0000-0002-2022-7769

András Kelemen (iD https://orcid.org/0000-0002-2480-5669

Silvia Del Vecchio iD https://orcid.org/0000-0001-8458-0433

Gabriella Buffa (iD) https://orcid.org/0000-0002-0862-637X

Péter Török iD https://orcid.org/0000-0002-4428-3327

\section{REFERENCES}

Aarssen, L. W., Schamp, B. S., \& Pither, J. (2006). Why are there so many small plants? Implications for species coexistence. Journal of Ecology, 94, 569-580. https://doi.org/10.1111/j.1365-2745.2006.01128.x

Albert, A. J., Kelemen, A., Valkó, O., Miglécz, T., Csecserits, A., Rédei, T., ... Török, P. (2014). Secondary succession in sandy old-fields: A promising example of spontaneous grassland recovery. Applied Vegetation Science, 17, 214-224. https://doi.org/10.1111/avsc.12068

Anderson, M. J. \& Ter Braak, C. (2003). Permutation tests for multifactorial analysis of variance. Journal of Statistical Computation and Simulation, 73, 85-113. https://doi.org/10.1080/00949650215733

Armbruster, W. S. (1995). The origins and detection of plant community structure: Reproductive versus vegetative processes. Folia Geobotanica et Phytotaxonomica, 30, 483-497. https://doi. org/10.1007/bf02803978

Bakker, J. P. \& van Diggelen, R. (2006). Restoration of dry grasslands and heathlands. In J. van Andel, \& J. Aronson (Eds.), Restoration ecology. The new frontier (pp. 95-110). Oxford, UK: Blackwell Publishing.

Bastian, O. (2013). The role of biodiversity in supporting ecosystem services in Natura 2000 sites. Ecological Indicators, 24, 12-22. https:// doi.org/10.1016/j.ecolind.2012.05.016

Biró, M., Révész, A., Molnár, Z., Horváth, F., \& Czúcz, B. (2008). Regional habitat pattern of the Duna-Tisza köze in Hungary II. The sand, the steppe and the riverine vegetation; degraded and regenerating habitats, regional habitat destruction. Acta Botanica Hungarica, 50, 19-60.

Borhidi, A., Kevey, B., \& Lendvai, G. (2012). Plant communities of Hungary. Budapest, Hungary: Akadémiai Kiadó.

Catorci, A., Cesaretti, S., Gatti, R., \& Tardella, F. M. (2012). Trait-related flowering patterns in submediterranean mountain meadows. Plant Ecology, 213, 1315-1328.
Chelli, S., Marignani, M., Barni, E., Petraglia, A., Puglielli, G., Wellstein, C., ... Cerabolini, B. E. L. (2019). Plant-environment interactions through a functional traits perspective: a review of Italian studies. Plant Biosystems. https://doi.org/10.1080/11263504.2018.15592 50

Cornelissen, J. H. C., Lavorel, S., Garnier, E., Díaz, S., Buchmann, N., Gurvich, D. E., ... Poorter, H. (2003). A handbook of protocols for standardised and easy measurement of plant functional traits worldwide. Australian Journal of Botany, 51, 335-380. https://doi. org/10.1071/bt02124

Cortés-Flores, J., Andresen, E., Cornejo-Tenorio, G., \& IbarraManriquez, G. (2013). Fruiting phenology of seed dispersal syndromes in a Mexican neotropical temperate forest. Forest Ecology and Management, 289, 445-454. https://doi.org/10.1016/j. foreco.2012.10.038

Couvreur, M., Christiaen, B., Verheyen, K., \& Hermy, M. (2004). Large herbivores as mobile links between isolated nature reserves through adhesive seed dispersal. Applied Vegetation Science, 7, 229-236. https://doi.org/10.1111/j.1654-109X.2004.tb00614.x.

Csecserits, A., Czúcz, B., Halassy, M., Kröel-Dulay, G., Rédei, T., Szabó, R., ... Török, K. (2011). Regeneration of sandy old-fields in the forest steppe region of Hungary. Plant Biosystems, 145, 715-729. https:// doi.org/10.1080/11263504.2011.601340

Del Vecchio, S., Slaviero, A., Fantinato, E., \& Buffa, G. (2016). The use of plant community attributes to detect habitat quality in coastal environments. AoB Plants, 8, plw040. https://doi.org/10.1093/aobpla/ plw040

Dengler, J., Janišová, M., Török, P., \& Wellstein, C. (2014). Biodiversity of Palaearctic grasslands: A synthesis. Agriculture Ecosystems and Environment, 182, 1-14. https://doi.org/10.1016/j.agee.2013. 12.015

Edwards, A. R., Mortimer, S. R., Lawson, C. S., Westbury, D. B., Harris, S. J., Woodcock, B. A., \& Brown, V. K. (2007). Hay strewing, brush harvesting of seed and soil disturbance as tools for the enhancement of botanical diversity in grasslands. Biological Conservation, 134, 372382. https://doi.org/10.1016/j.biocon.2006.08.025

Escaravage, N. \& Wagner, J. (2004). Pollination effectiveness and pollen dispersal in a Rhododendron ferrugineum (Ericaceae) population. Plant Biology, 6, 606-615. https://doi.org/10.1055/s-2004-821143

Fantinato, E., Del Vecchio, S., Baltieri, M., Fabris, B., \& Buffa, G. (2017). Are food-deceptive orchid species really functionally specialized for pollinators? Ecological Research, 32, 951-959. https://doi. org/10.1007/s11284-017-1501-0

Fantinato, E., Del Vecchio, S., Gaetan, C., \& Buffa, G. (2019). The resilience of pollination interactions: Importance of temporal phases. Journal of Plant Ecology, 12, 157-162. https://doi.org/10.1093/jpe/ rty005

Fantinato, E., Del Vecchio, S., Giovanetti, M., Acosta, A. T. R., \& Buffa, G. (2018). New insights into plants coexistence in species-rich communities: The pollination interaction perspective. Journal of Vegetation Science, 29, 6-14. https://doi.org/10.1111/jvs.12592

Fantinato, E., Del Vecchio, S., Slaviero, A., Conti, L., Acosta, A. T. R., \& Buffa, G. (2016). Does flowering synchrony contribute to the sustainment of dry grassland biodiversity? Flora, 222, 96-103. https:// doi.org/10.1016/j.flora.2016.04.003

Fantinato, E., Giovanetti, M., Del Vecchio, S., \& Buffa, G. (2016). Altitudinal patterns of floral morphologies in dry calcareous grasslands. Plant Sociology, 53, 83-90.

Götzenberger, L., de Bello, F., Bråthen, K. A., Davison, J., Dubuis, A., Guisan, A., ... Zobel, M. (2012). Ecological assembly rules in plant communities - approaches, patterns and prospects. Biological Reviews, 87, 111-127. https://doi.org/10.1111/j.1469-185x.2011.00187.x

Grime, J. P. (2001). Plant strategies: Vegetation processes and ecosystem properties. Chichester, UK: Wiley. 
Hammer, Ø., Harper, D. A. T., \& Ryan, P. D. (2001). PAST: Paleontological statistics software package for education and data analysis. Paleontologia Electronica, 4(1), 1-9.

Hedberg, P. \& Kotowski, W. (2010). New nature by sowing? The current state of species introduction in grassland restoration, and the road ahead. Journal for Nature Conservation, 18, 304-308. https://doi. org/10.1016/j.jnc.2010.01.003

Heystek, A. \& Pauw, A. (2014). Does competition for pollinators contribute to structuring Erica communities? Journal of Vegetation Science, 25(3), 648-656. https://doi.org/10.1111/jvs.12127

Hurst, A. \& John, E. (1999). The biotic and abiotic changes associated with Brachypodium pinnatum dominance in chalk grassland in south-east England. Biological Conservation, 88, 75-84. https://doi.org/10.1016/ s0006-3207(98)00089-5

Jentsch, A. \& Beyschlag, W. (2003). Vegetation ecology of dry acidic grasslands in the lowland area of central europe. Flora, 198, 3-25. https://doi.org/10.1078/0367-2530-00071

Jones, M. B. \& Donnelly, A. (2004). Carbon sequestration in temperate grassland ecosystems and the influence of management, climate and elevated $\mathrm{CO}_{2}$. New Phytologist, 164, 423-439. https://doi. org/10.1111/j.1469-8137.2004.01201.x

Kahmen, A., Perner, J., \& Buchmann, N. (2005). Diversity-dependent productivity in semi-natural grasslands following climate perturbations. Functional Ecology, 19, 594-601. https://doi. org/10.1111/j.1365-2435.2005.01001.x

Kandziora, M., Burkhard, B., \& Müller, F. (2013). Interactions of ecosystem properties, ecosystem integrity and ecosystem service indicators - A theoretical matrix exercise. Ecological Indicators, 28, 54-78. https://doi.org/10.1016/j.ecolind.2012.09.006

Keddy, P. A. (1992). Assembly and response rules: Two goals for predictive community ecology. Journal of Vegetation Science, 3, 157-164. https://doi.org/10.2307/3235676

Keddy, P., Nielsen, K., Weiher, E., \& Lawson, R. (2002). Relative competitive performance of 63 species of terrestrial herbaceous plants. Journal of Vegetation Science, 13, 5-16. https://doi. org/10.1111/j.1654-1103.2002.tb02018.x

Kelemen, A., Lazzaro, L., Besnyői, V., Albert, Á.-J., Konečná, M., Dobay, G., ... Lepš, J. (2015). Net outcome of competition and facilitation in a wet meadow changes with plant's life stage and community productivity. Preslia, 87, 347-361.

Kelemen, A., Valkó, O., Kröel-Dulay, G., Deák, B., Török, P., Tóth, K., ... Tóthmérész, B. (2016). The invasion of common milkweed (Asclepias syriaca L.) in sandy old-fields - is it a threat to the native flora? Applied Vegetation Science, 19, 218-224. https://doi.org/10.1111/ avsc.12225

Kiehl, K., Kirmer, A., Donath, T. W., Rasran, L., \& Hölzel, N. (2010). Species introduction in restoration projects-Evaluation of different techniques for the establishment of semi- natural grasslands in Central and Northwestern Europe. Basic and Applied Ecology, 11, 285-299. https://doi.org/10.1016/j.baae.2009.12.004

Kugler, H. (1970). Blütenökologie. Stuttgart, Germany: Gustav Fischer Verlag.

Kühn, I., Durka, W., \& Klotz, S. (2004). BiolFlor: A new plant-trait database as a tool for plant invasion ecology. Diversity and Distribution, $10,363-365$.

Liira, J., Zobel, K., Mägi, R., \& Molenberghs, G. (2002). Vertical structure of herbaceous canopies: The importance of plant growth-form and species-specific traits. Plant Ecology, 163, 123-134. https://doi. org/10.1023/a:1020365402855

Mason, N. W. H., Pipenbaher, N., Škornik, S., \& Kaligarič, M. (2013). Does complementarity in leaf phenology and inclination promote co-existence in a species-rich meadow? Evidence from functional groups. Journal of Vegetation Science, 24, 94-100. https://doi. org/10.1111/j.1654-1103.2012.01451.x
Müller-Schenider, P. (1986). Verbreitungsbiologie der Blütenpflanzen Graubündens. Zürich, Switzerland: Geobotanisches Institut der ETH, Stiftung Rübel.

Öckinger, E. \& Smith, H. G. (2007). Semi-natural grasslands as population sources for pollinating insects in agricultural landscapes. Journal of Applied Ecology, 44, 50-59.

Osbornová, J., Kovářová, M., Lepš, J., \& Prach, K. (1990). Succession in abandoned fields: Studies in Central Bohemia, Czechoslovakia. Dordrecht, The Netherlands: Kluwer Academic.

Pellissier, L., Pottier, J., Vittoz, P., Dubuis, A., \& Guisan, A. (2010). Spatial pattern of floral morphology: possible insight into the effects of pollinators on plant distributions. Oikos, 119, 1805-1813. https://doi. org/10.1111/j.1600-0706.2010.18560.x

Pérez-Harguindeguy, N., Díaz, S., Garnier, E., Lavorel, S., Poorter, H., Jaureguiberry, P., ... Cornelissen, J. H. C. (2013). New handbook for standardised measurement of plant functional traits worldwide. Australian Journal of Botany, 61, 137-234.

Poschlod, P., Bakker, J. P., \& Kahmen, S. (2005). Changing land use and its impact on biodiversity. Basic and Applied Ecology, 6, 93-98. https:// doi.org/10.1016/j.baae.2004.12.001

Prach, K. \& Hobbs, R. J. (2008). Spontaneous succession versus technical reclamation in the restoration of disturbed sites. Restoration Ecology, 16, 363-366. https://doi.org/10.1111/j.1526-100x.2008.00412.x

Prach, K., Jongepierová, I., Řehounková, K., \& Fajmon, K. (2014). Restoration of grasslands on ex-arable land using regional and commercial seed mixtures and spontaneous succession: Successional trajectories and changes in species richness. Agriculture Ecosystems and Environment, 182, 131-136. https://doi.org/10.1016/j. agee.2013.06.003

Prach, K., Tichý, L., Lencová, K., Adámek, M., Koutecký, T., Sádlo, J., ... Řehounková, K. (2016). Does succession run towards potential natural vegetation? An analysis across seres. Journal of Vegetation Science, 27, 515-523. https://doi.org/10.1111/jvs.12383

Pullin, A. S., Báldi, A., Can, O. E., Dietrich, M., Kati, V., Livoreil, B., ... Sousa-Pinto, I. (2009). Conservation focus on Europe: Major conservation policy issues that need to be informed by conservation science. Conservation Biology, 23, 818-824. https://doi. org/10.1111/j.1523-1739.2009.01283.x

Purschke, O., Schmid, B. C., Skyes, M. T., Poschlod, P., Michalski, S. G., Durka, W., ... Prentice, H. C. (2013). Contrasting changes in taxonomic, phylogenetic and functional diversity during a long-term succession: insights into assembly processes. Journal of Ecology, 101, 857-866. https://doi.org/10.1111/1365-2745.12098

Reader, R. J. \& Best, B. J. (1989). Variation in competition along an environmental gradient: Hieracium floribundum in an abandoned pasture. Journal of Ecology, 77, 673-684. https://doi. org/10.2307/2260977

Schamp, B., Hettenbergerová, E., \& Hájek, M. (2011). Testing community assembly predictions for nominal and continuous plant traits in species-rich grasslands. Preslia, 83, 329-346.

Slaviero, A., Del Vecchio, S., Pierce, S., Fantinato, E., \& Buffa, G. (2016). Plant community attributes affect dry grassland orchid establishment. Plant Ecology, 217, 1533-1543. https://doi.org/10.1007/ s11258-016-0666-x

Thomson, J. D. \& Wilson, P. (2008). Explaining evolutionary shift between bee and hummingbird pollination: convergence, divergence and directionality. International Journal of Plant Sciences, 169, 23-38. https://doi.org/10.1086/523361

Török, P., Matus, G., Papp, M., \& Tóthmérész, B. (2008). Secondary succession in overgrazed Pannonian sandy grasslands. Preslia, 80, 73-85.

Török, P., Vida, E., Deák, B., Lengyel, S., \& Tóthmérész, B. (2011). Grassland restoration on former croplands in Europe: an assessment of applicability of techniques and costs. Biodiversity and Conservation, 20, 2311-2332. https://doi.org/10.1007/s10531-011-9992-4 
van der Maarel, E. \& Sykes, M. T. (1993). Small-scale plant species turnover in a limestone grassland: the carousel model and some comments on the niche concept. Journal of Vegetation Science, 4, 179188. https://doi.org/10.2307/3236103

Valkó, O., Török, P., Matus, G., \& Tóthmérész, B. (2012). Is regular mowing the most appropriate and cost-effective management maintaining diversity and biomass of target forbs in mountain hay meadows? Flora, 207, 303-309. https://doi.org/10.1016/j.flora.2012.02.003

Vamosi, J. C., Armbruster, W. S., \& Renner, S. S. (2014). Evolutionary ecology of specialization: insights from phylogenetic analysis. Proceeding of the Royal Society B: Biological Sciences, 281, 20142004. https://doi. org/10.1098/rspb.2014.2004

Vittoz, P. \& Engler, R. (2007). Seed dispersal distances: a typology based on dispersal modes and plant traits. Botanica Helvetica, 117, 109-124. https://doi.org/10.1007/s00035-007-0797-8

Wellstein, C., Campetella, G., Spada, F., Chelli, F., Mucina, L., Canullo, R., $\&$ Bartha, S. (2014). Context-dependent assembly rules and the role of dominating grasses in semi-natural abandoned sub-Mediterranean grasslands. Agriculture Ecosystems and Environment, 182, 113-122. https://doi.org/10.1016/j.agee.2013.12.016

Westerkamp, C. \& Claßen-Bockhoff, R. (2007). Bilabiate flowers: the ultimate response to bees? Annals of Botany, 100, 361-374. https://doi. org/10.1093/aob/mcm123

Willmer, P. (2011). Pollination and floral ecology. Princeton, NJ: Princeton University Press.

Wilson, J. B. (1999). Assembly rules in plant communities. In E. Weiher, \& P. Keddy (Eds), Ecological assembly rules: Perspectives, advances, retreats (pp. 130-164). Cambridge, UK: Cambridge University Press. https://doi.org/10.1017/cbo9780511542237

Wilson, J. B. \& Gitay, H. (1995). Limitations to species coexistence: evidence for competition from field observations, using a patch model. Journal of Vegetation Science, 6, 369-376. https://doi. org/10.2307/3236236

Wilson, S. D. \& Keddy, P. A. (1986). Species competitive ability and position along a natural stress/disturbance gradient. Ecology, 67, 12361242. https://doi.org/10.2307/1938679

\section{SUPPORTING INFORMATION}

Additional supporting information may be found online in the Supporting Information section at the end of the article.

Appendix S1. Recorded plant species list. For each species, the frequency of occurrence in each old-field and reference grassland type, as well as reproductive and vegetative traits (i.e., pollination strategy, dispersal mode, and growth form) is reported.

How to cite this article: Fantinato E, Sonkoly J, Silan G, et al. Pollination and dispersal trait spectra recover faster than the growth form spectrum during spontaneous succession in sandy old-fields. Appl Veg Sci. 2019;22:435-443. https://doi. org/10.1111/avsc.12439 